\title{
(Marketing Efficiency and Value Chain Analysis: The Case of Garlic Crop in Bangladesh
}

\section{Md. Kamrul Hasan, K. M. Khalequzzaman*}

Senior Scientific Officer, Spices Research Centre, Bangladesh Agricultural Research Institute Shibganj, Bogra, BANGLADESH

*E-mail for correspondence: zaman.path@gmail.com

Received: Mar 29, 2016;

Source of Support: Nil
Accepted: Nov 30, 2016;

Published: Jan 01, 2017

No Conflict of Interest: Declared

\begin{abstract}
Garlic is a highly profitable crop and is largely used both in medicinal and culinary purposes. The study was undertaken to determine marketing system, marketing cost, marketing margin, marketing efficiencies and to examine the value chain of garlic aiming to determine the value addition in different steps of garlic marketing. A purposive and simple randomized sampling procedure was used in selecting primary data. Marketing margin, profit, efficiency ratio, value addition etc. were calculated by different relevant equations and formulas. Four major marketing channels were identified for domestic produced garlic marketing. Channel-3 was the most important supply chain through which $40 \%$ domestic produced garlic reaches to consumers. Marketing margin and profit were the highest in retailer than those of other intermediaries. Out of four marketing channel, Channel-2 was more efficient than those of other channels. Six actors like; farmer, local trader, trader, commission agent, wholesaler, retailer and consumer are identified who are involved in the garlic value chain activities. Retailer added highest amount of value per unit of garlic and that of the lowest in wholesaler. Eleven marketing problem were identified, among them price fluctuation, high transport cost and lack of loan facilities were the major problem. It is therefore, recommended that Government intervention is urgent necessary to stabilize the price of garlic, loan facilities should be provided to the intermediaries and transportation cost should be kept reasonable.
\end{abstract}

Keywords: Garlic, marketing system, marketing efficiency and value chain

\section{INTRODUCTION}

Garlic is one of the most important bulb crops grown and used as a spice or a condiment throughout in Bangladesh. It is widely used as spice in various ways in all curries, fried, seasoning dishes, pickles, sauces and for other purposes. It adds flavour of distinctive pungent and has medicinal values also. Garlic has become an increasingly popular spice in recent years among producers, marketers and consumers. More people are discovering its culinary splendor, and producers have found garlic to be a potentially highly profitable crop. Bangladesh produces 223.69 thousand metric tonnes of garlic per year that are mostly added in value chain activities.

Garlic is the crop in Bangladesh whose price fluctuates is more. Therefore, this crop is faced with the highest risk and uncertainty. Besides, problems in garlic pricing also negatively affect the production since the prices of garlic produces are generally determined under market conditions. However, there is not an effective organization in the production and marketing of garlic in Bangladesh. Prices in the market are formed based on supply and demand principles rather than production costs. In most cases, poor storability and seasonality lead to market variations in quantity and quality of garlic and its associated price swings. The rising consumer price for garlic may be an indication of market inefficiency.

The nonfarm dimensions of rural development particularly in agricultural marketing and agroprocessing often prove critical to successful agricultural growth (Abbott 1986). Without well-functioning agricultural markets, productivity gains on the farm lead to temporary production surges and price collapses. Improved market access proves necessary for maintaining production incentives, permitting household specialization and enabling movement to high-value products and to value-added activities. Value chains provide a valuable visual framework for understanding the structural connective tissue linking small farmers with input suppliers, processors, traders and final consumers. 
In highly competitive and increasingly global agribusiness markets, poor households must find niches in which they can compete effectively in the rapidly growing urban, rural and export markets. Yet the large agribusiness that increasingly drive change in agricultural value chains seek to reduce costs and raise profits, often by scaling up production and market share, reducing the number of suppliers they deal with and squeezing supplier prices (Reardon and Timmer, 2007).

Marketing in developing countries like Bangladesh is beset with a lot of problems, which constitute a bottleneck to the flow of goods and services. Such problems include seasonal variations, transportation of harvested produce, storage, processing, grading and communication (Ikechi et al., 2006). According to Arene (1999) efficiency is used to evaluate marketing performance. Performance can be achieved using the following approaches-marketing margin, net-returns and marketing efficiency ratios. Therefore, there is the need to assess the performance of the market to determine the efficiency of the garlic marketing system in Bangladesh. Despite the research and development efforts in improving the production and productivity of garlic in Bangladesh, little has been done to improve the performance of the entire garlic value chain. Garlic production rose from 38.55 thousand metric tonnes in 1996 to 223.69 thousand metric tonnes in 2013 (BBS, 1998 and BBS, 2015). These increases were attributed to improved technological inputs, and national research efforts.

But there is no policy to encourage farmers to produce exportable surplus, consequently, supplies are often unreliable. There is lack of information regarding markets for garlic, especially among the producers and traders. Farmers are not getting fair price because of their low bargaining power, lack of market information, poor storage facilities, immediate cash need etc. Therefore, the study was taken to measure the existing marketing system, marketing margin, marketing efficiency and finally to examine the value chain of garlic aiming to determine the value addition in different steps of marketing channel. However, the study undoubtedly important to business men, farmers as well as to policy makers for planning future production, import, export, price stabilization measures, etc. with the following objectives.

\section{Materials ANd Methods}

Primary data were used for the study. For the collection of primary data, three districts namely Dinajpur, Natore and Rajbari were selected purposively depending upon the concentration of production and commercially marketing of garlic. In these study areas, three types of market such as primary, secondary and consumer market were selected. However, to examine the value chain of garlic aiming to determine the value added to marketed garlic in different steps of marketing channel, city markets of Dhaka and Bogra were selected.

Purposive and simple random sampling techniques were used to pick a sample. A total of 120 farmers taking 40 from each area were selected randomly. Thirty six (36) local traders (collectors), 45 trader (traders), 15 Commission agent (commission agent), 30 wholesalers and 30 retailers were selected from the above selected areas including major consuming area Dhaka and Bogra. Two sets of pre-tasted interview schedule, one for farmers and other for intermediaries were used for the collection of data/information using survey method. Primary data were collected by face-to-face interview during 2013-14 crop seasons. The study was conducted only for domestic produced garlic in Bangladesh.

\section{Analytical technique}

The collected data and information were reduced to tabular form which included classification of tables into meaningful results by using arithmetic mean, percentage and ratio. For garlic marketing, intermediaries involved in marketing channel were identified and marketing costs, margins, and profits of intermediaries were determined by using tables and flow diagrams. Value chain and value addition to garlic was shown by using flow channel and table. Except this, the following analytical techniques were used for the study.

\section{- Cost and return analysis}

Following profit equation was employed to assess the profitability of production.

$\pi=\mathrm{PF}_{\mathrm{F}} \mathrm{Q} \mathrm{F}-(\mathrm{TVC}+\mathrm{TFC})$

Where, $\pi=$ Profit of producer per hectare, $\mathrm{P}_{\mathrm{F}}=$ per unit price of garlic $(\mathrm{Tk} / 100 \mathrm{~kg}), \mathrm{QF}_{\mathrm{F}}=$ Quantity of garlic $\left(\mathrm{Q}_{\mathrm{t}} / \mathrm{ha}\right), \mathrm{TVC}=$ Total variable cost garlic, $\mathrm{TFC}=$ Total fixed cost of garlic

\section{- Marketing Efficiency}

Measuring marketing efficiency: Efficient marketing plays an important role in increasing the producer's share in consumer's taka and maintains the tempo of increased production. Four indicators were used for measuring efficiency in different marketing channels. These indicators are (i) marketing cost; (ii) marketing margin (iii) marketing profit and (iii) percentage of producer's share of garlic. 
Marketing cost: The total marketing cost was determined by the following formula

\section{$T c=C p+\sum M c i$}

Where, $\mathrm{T} c=$ Total cost of marketing, $\mathrm{Cp}=$ Producer cost of marketing

Mci= Marketing cost by the ith trader

The cost of marketing was calculated and the lowest cost marketing channel was ranked (I) and that which was highest cost as the last. The same approach was followed in ranking the margin of middlemen in each channel.

Marketing margin: The absolute margin of the middleman, wholesaler, trader and retailers were determined by the following formula

$\mathrm{MM}=\mathrm{SP}-\mathrm{PP}$

Where, $\mathrm{MM}=$ Marketing margin, $\mathrm{SP}=$ Selling price, $\mathrm{PP}=$ Purchase price,

Marketing profit: Marketing profit was calculated by the following formula and the channel which was lowest marketing profit was ranked (I) and that which highest profit as the last.

$\mathrm{MP}=\mathrm{MM}-\mathrm{MC}$

$\mathrm{MP}=$ Marketing Profit, $\mathrm{MM}=$ Marketing Margin, $\mathrm{MC}=$ Marketing Cost

Producer's share: The producer's share was calculated by the following formula and the channel which was highest producer's share was ranked (I) and first and vice- versa.

Percentage of producers' share $=\frac{P_{p i}}{P_{r i}} X 100$

Where, $\mathrm{P}_{\mathrm{p} i}=$ Producer's share in the ith channel, $\mathrm{P}_{\mathrm{ri}}=$ Average price at the retail level in each channel, $\mathrm{i}=$ Number of channels $(i=1,2 \ldots \ldots \ldots ., n)$

Marketing efficiency: Marketing efficiency is a complicated topic to be defined. It carries different meanings to different persons. Four methods like i) Shephred Method ii) Acharya and Agarwal Method iii) Composite Index Method and iv) Marketing Efficiency Index Method are usually used to calculate the marketing efficiency. However, Composite Index method was followed to estimate marketing efficiency for the present study. As per this method, the percentage of producer's price, marketing cost, marketing margin and marketing profit per $100 \mathrm{~kg}$ of garlic was calculated and these were assigned ranks. Total scores were found by adding the respective ranks in each channel. The mean scores were calculated for each channel. Where the mean score was less, it was efficient channel.
$R=\frac{R_{i}}{N_{i}}$

Where, $\mathrm{R}_{\mathrm{i}}=$ Total value of ranks of all indicators $\left(\mathrm{I}_{1}, \mathrm{I}_{2} \mathrm{I}_{3}\right.$ and $\mathrm{I}_{4}$ ),

$\mathrm{N}_{\mathrm{i}}=$ Number of indicators

\section{- Value addition by traders}

Value addition $=$ Gross value addition-Marketing cost

Gross value addition $=$ Sale price-Purchase price

\section{Results AND Discussion}

\section{Marketing and Value Chain System of Garlic}

Marketing is the connecting link between the producers and consumers. Through marketing system, garlic being a semi perishable commodity, reaches the consumer in acceptable condition. The marketing system operates through a set of intermediaries performing useful commercial functions in a chain all the way from the producers to the final consumers.

An efficient marketing system is essential for earning fair profit for the garlic farmers and traders. In the study areas, the whole marketing of garlic has been broken down into various functions such as buying and selling, transportation, grading, storing, weighing, market information and pricing.

\section{Involvement stakeholders and intermediaries}

The major intermediaries performed marketing functions are farmer, local traders, trader, commission agent, wholesaler, retailers and consumers. This section described the function of all these intermediaries involved in marketing chain of garlic.

Farmer: The farmers in Natore, Rajbari and Dinajpur often sell their garlic at home to local trader or at local market to local trader or trader. In few cases, the farmer sold their garlic to wholesaler, retailer and consumer in order to have good price. The farmers sold $75 \%$ of their garlic to trader and $17 \%$ to local trader. Farmer also sold a few amount of garlic to wholesaler (3\%) and retailer $(4 \%)$ through commission agent (Table 1).

Local trader: Local traders are usually operating in the garlic marketing system who purchases small quantity $(400-600 \mathrm{~kg})$ of garlic from farmer from their houses or from the local market and carry it to the terminal point and sell $100 \%$ of garlic to trader (Table 1).

Trader: In garlic marketing, trader are professional garlic traders and they purchase $75 \%$ of garlic from farmer and $25 \%$ from local trader and sell their consignment to the wholesalers $(30 \%)$ and retailers $(70 \%)$ through commission agent (Table 1). Usually, they purchase garlic from the farmer in local market and bring their garlic to different district's commission agent centre for sale. They are professional businessmen and have wide experience in garlic marketing. 
Commission agent: The commission agent is a main actor in the garlic distribution system. A commission agent arranges or negotiates sales for the sellers on commission basis. Commission agent has a fixed establishment and helps the trader to sell their products and charges usually a fixed commission of Tk 80.11 per $100 \mathrm{~kg}$ garlic sales revenue. They provide short period storage facilities and also help to perform the function of grading. Sometimes the commission agent advance loan to trader on the condition that the trader have to sell garlic through them. Commission agents are also organized and they need license for operating the business.

Table 1: Percent of garlic transacted by value chain actors

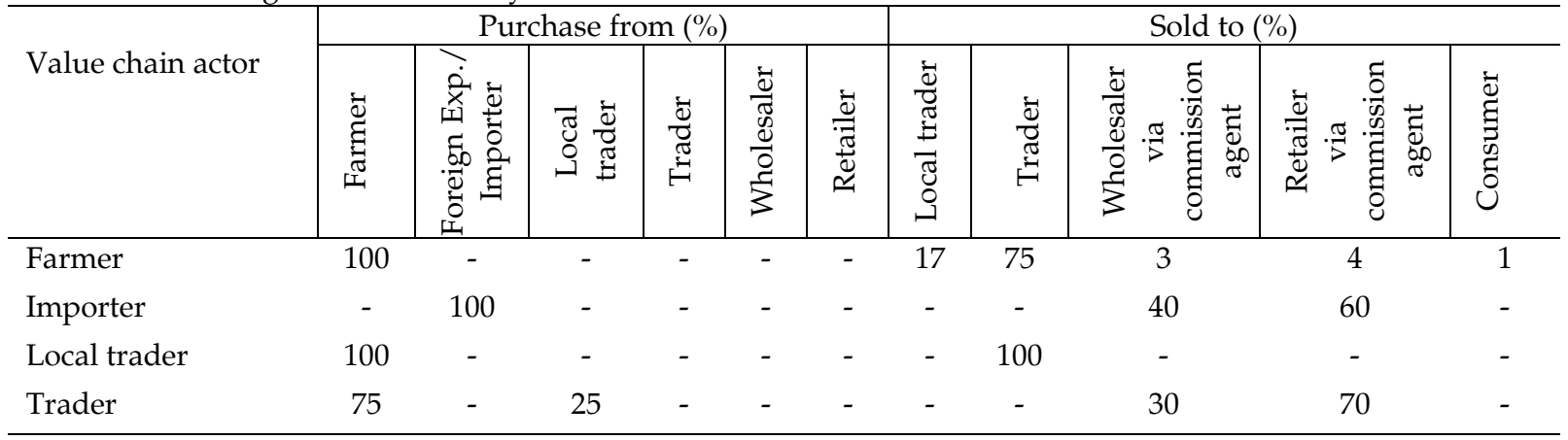

Commission agent Commission agent negotiates between buyers and sellers of garlic and helps them at their own business premises on receipt of commission agent commission.

\begin{tabular}{lccccccccccc}
\hline Wholesaler & 2 & 20 & - & 78 & - & - & - & - & - & 100 & - \\
Retailer & 3 & 12 & - & 41 & 44 & - & - & - & - & - & 100 \\
Consumer & 1 & - & - & - & - & 99 & - & - & - & - & -
\end{tabular}

Wholesalers: Wholesalers are the secondary traders who transact large volume of product. They purchase most of the garlic $(78 \%)$ from trader through commission agent from district market and sell their entire product to district or upazila retailer. Wholesaler sold $100 \%$ of their garlic to retailer.

Retailers: The retailers form the last link in the garlic marketing chain. They buy most of garlic from wholesaler $(44 \%)$ and trader $(41 \%)$ through commission agent. Retailers sold the entire garlic to ultimate consumers (Table 1).

\section{Marketing and Supply Channel of Garlic}

Marketing channels are the alternative routes of product flows from producers to consumers (Kohls and Uhl 2005). The supply chain for garlic can involve a large number of stakeholders between farmer and the final consumer. The entire set of processes and activities required to produce a product and these deliver to a target market is considered as supply chain.

Flow chart 1 showed the two ways distribution and supply chain of garlic. One is farmer produced which come to market after storage and processing. Other supply chain is where usually imported garlic is being distributed through marketing channel. Flow Chart 1 and Appendix Table 1 and Table 2 showed how garlic is being distributed from farmer or importer to ultimate consumers through intermediaries involved in supply chain of marketing system.

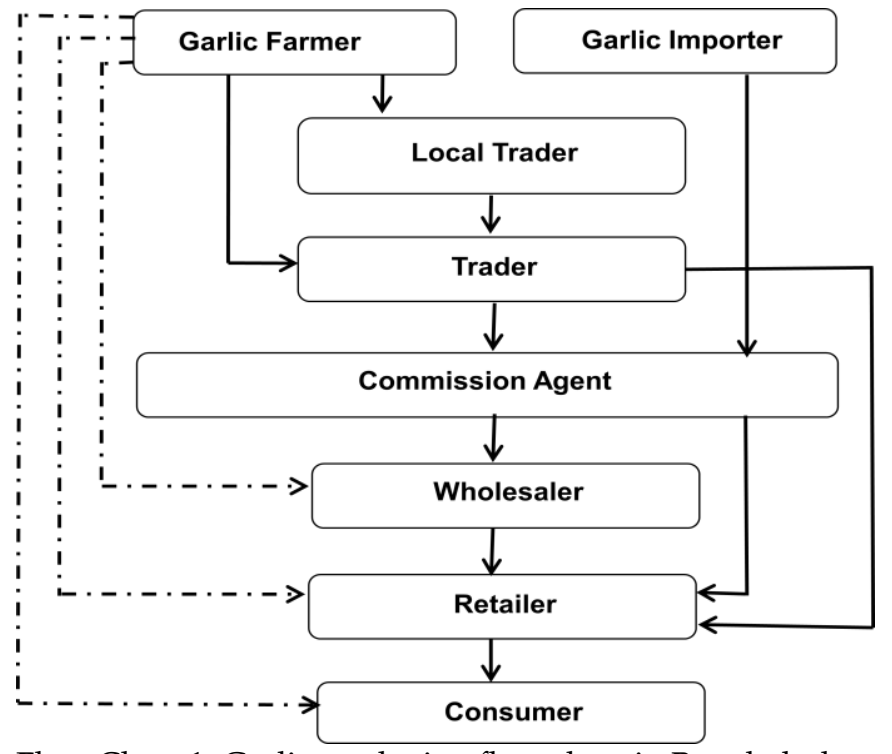

Flow Chart 1: Garlic marketing flow chart in Bangladesh

$$
\text { Major flow -... Minor flow }
$$

In the channel of garlic marketing in Bangladesh, the product moves from producer to ultimate consumer through a number of market intermediaries. There prevailed a several number of marketing channels of garlic in the study areas (Appendix Table 1). But all the channels were not equally important in the study area. Some channel handled only a negligible portion of supply of garlic. According to the volume of garlic handled and longevity or participation of the middlemen in the channel; the following four channels were identified as dominant in marketing of domestic garlic. So, the efficiency of the following four major channels was measured. 
Table 2: Major marketing channel for domestic garlic production

\begin{tabular}{|c|c|c|c|}
\hline Channel & Marketing channel & $\begin{array}{c}\% \text { of } \\
\text { garlic run }\end{array}$ & Rank \\
\hline 1. & Farmer $\rightarrow$ Local trader $\rightarrow$ Trader $\rightarrow$ Commission agent $\rightarrow$ Wholesaler $\rightarrow$ Retailer $\rightarrow$ Consumer & 14 & III \\
\hline 2. & Farmer $\rightarrow$ Trader $\rightarrow$ Commission agent $\rightarrow$ Wholesaler $\rightarrow$ Retailer $\rightarrow$ Consumer & 20 & II \\
\hline 3. & Farmer $\rightarrow$ Trader $\rightarrow$ Commission agent $\rightarrow$ Retailer $\rightarrow$ Consumer & 40 & I \\
\hline 4. & Farmer $\rightarrow$ Wholesaler $\rightarrow$ Retailer $\rightarrow$ Consumer & 3 & VII \\
\hline
\end{tabular}

Source: Field survey 2013-14

Table 2 showed, Channel-3 (Farmer $\rightarrow$ Trader $\rightarrow$ Commission agent $\rightarrow$ Retailer $\rightarrow$ Consumer) is the most important supply chain of which through $40 \%$ domestic produced garlic reaches to consumers. $20 \%$ of garlic runs through the Channel-2 (Farmer $\rightarrow$ Trader $\rightarrow$ Commission agent $\rightarrow$ Wholesaler $\rightarrow$ Retailer $\rightarrow$ Consumer) and $14 \%$ through Channel-1 (Farmer $\rightarrow$ Local trader $\rightarrow$ Trader $\rightarrow$ Commission agent $\rightarrow$ Wholesaler $\rightarrow$ Retailer $\rightarrow$ Consumer). Only 3\% garlic run through the Channel-4 from farmer to consumer.

\section{Marketing Cost, Margin and Profit of Different Intermediaries}

According to Kohls and Uhl (2005), marketing margin in a sense is the price of all utility adding activities and functions that are performed by the intermediaries. Total marketing margin is the difference between the price received by farmer and the price paid by the final consumers. Marketing margin and marketing cost are usually used to estimate the profitability of intermediaries involved in garlic marketing. However, marketing cost and marketing margin of respective categories of intermediaries are the main determinants of the profitability in marketing of garlic.

\section{Marketing cost at different levels of market}

Marketing costs of garlic represent the cost of performing various marketing functions which are needed to transfer garlic from the place of production to the ultimate consumers.

Table 3: Marketing cost of stakeholders and intermediaries involved in garlic trading (Tk/100 kg) in domestic market

\begin{tabular}{|c|c|c|c|c|c|c|c|c|}
\hline Cost items & 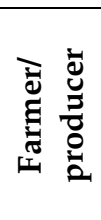 & 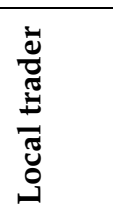 & 预 & 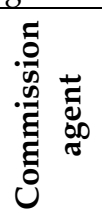 & $\begin{array}{l}\frac{\grave{d}}{\pi} \\
\frac{0}{0} \\
\frac{2}{3}\end{array}$ & 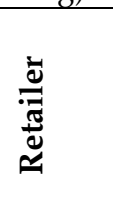 & $\underset{7}{7}$ & 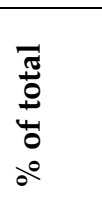 \\
\hline Storage & 8.11 & 8.31 & 10.01 & 0 & 10.21 & 0 & 36.64 & 3.25 \\
\hline Sorting & 25.12 & 15.02 & 16.13 & 0 & 0 & 0 & 56.27 & 4.99 \\
\hline Weighing and Packaging & 0 & 5.26 & 7.51 & 7.52 & 5.25 & 0 & 25.54 & 2.26 \\
\hline Loading and unloading & 0 & 0 & 20.24 & 0 & 22.11 & 0 & 42.35 & 3.75 \\
\hline Transportation & 25.24 & 25.11 & 90.17 & 0 & 54.41 & 40.15 & 235.08 & 20.83 \\
\hline Market tolls & 20.23 & 20.18 & 8.33 & 10.13 & 12.32 & 12.16 & 83.35 & 7.38 \\
\hline Wage and salaries & 0 & 15.23 & 25.21 & 12.11 & 25.34 & 0 & 77.89 & 6.90 \\
\hline Commission agent's commission & 0 & 0 & 80.11 & 0 & 0 & 25.15 & 105.26 & 9.33 \\
\hline House rent/Shop rent & 0 & 0 & 14.06 & 5.55 & 4.25 & 9.42 & 33.28 & 2.95 \\
\hline Electricity & 0 & 0 & 0.52 & 0.52 & 0.32 & 0.13 & 1.49 & 0.13 \\
\hline Telephone bill & 0 & 1.12 & 1.31 & 0.43 & 0.21 & 0.31 & 3.38 & 0.30 \\
\hline Personal expenses & 8.12 & 8.14 & 15.03 & 10.61 & 8.23 & 11.21 & 61.34 & 5.43 \\
\hline Tips and donation & 0 & 5 & 7.21 & 8.51 & 6.23 & 3.42 & 30.37 & 2.69 \\
\hline Wastage & 0 & 35.05 & 90.34 & 0 & 80.21 & 125.02 & 330.62 & 29.29 \\
\hline Others & 0 & 0 & 2.08 & 1.25 & 1.45 & 1.13 & 5.91 & 0.52 \\
\hline Total & $\begin{array}{l}86.82 \\
(7.69) \\
\end{array}$ & $\begin{array}{l}138.42 \\
(12.26)\end{array}$ & $\begin{array}{l}388.26 \\
(34.40) \\
\end{array}$ & $\begin{array}{l}56.63 \\
(5.02) \\
\end{array}$ & $\begin{array}{l}230.54 \\
(20.42) \\
\end{array}$ & $\begin{array}{l}228.10 \\
(20.21)\end{array}$ & $\begin{array}{l}1128.77 \\
(100.00)\end{array}$ & 100.00 \\
\hline
\end{tabular}

Source: Field survey 2013-14, $1 \$=80.00$ Taka

Note: Figures within parenthesis indicate percent of total marketing cost.

The payment of commission makes the marketing cost higher for trader than for retailers for garlic marketing. However, marketing costs per $100 \mathrm{~kg}$ of garlic were estimated to be Tk 86.82, 138.42 and 388.28 for farmer, local trader and trader, respectively. On the other hand, wholesaler and retailer expensed Tk 230.54 and 228.10 as marketing cost for garlic marketing, respectively (Table 3). Table 3 showed that of all marketing expenses, the transportation and wastage expense leads the total marketing cost irrespective of all intermediaries. 
Table 4: Marketing cost of indigenous garlic for different major channel (Tk/100 kg)

\begin{tabular}{|c|c|c|c|c|}
\hline \multirow[t]{2}{*}{ Cost Items } & \multicolumn{4}{|c|}{ Channel } \\
\hline & $\begin{array}{c}\text { Channel } \\
1\end{array}$ & \begin{tabular}{|c|} 
Channel \\
2
\end{tabular} & $\begin{array}{c}\text { Channel } \\
3\end{array}$ & $\begin{array}{c}\text { Channel } \\
4\end{array}$ \\
\hline Storage & 36.64 & 28.33 & 18.12 & 18.32 \\
\hline Sorting & 56.27 & 41.25 & 41.25 & 25.12 \\
\hline $\begin{array}{l}\text { Weighing and } \\
\text { Packaging }\end{array}$ & 25.54 & 20.28 & 15.03 & 5.25 \\
\hline $\begin{array}{l}\text { Loading and } \\
\text { unloading }\end{array}$ & 42.35 & 42.35 & 20.24 & 22.11 \\
\hline Transportation & 235.08 & 209.97 & 155.56 & 119.8 \\
\hline Market tolls & 83.35 & 63.17 & 50.85 & 44.71 \\
\hline Wage and salaries & 77.89 & 62.66 & 37.32 & 25.34 \\
\hline $\begin{array}{l}\text { Commission agent's } \\
\text { commission }\end{array}$ & 105.26 & 105.26 & 105.26 & 25.15 \\
\hline $\begin{array}{l}\text { House rent/ } \\
\text { Shop rent }\end{array}$ & 33.28 & 33.28 & 29.03 & 13.67 \\
\hline Electricity & 1.49 & 1.49 & 1.17 & 0.45 \\
\hline Telephone bill & 3.38 & 2.26 & 2.05 & 0.52 \\
\hline Personal expenses & 61.34 & 53.2 & 44.97 & 27.56 \\
\hline Tips and donation & 30.37 & 25.37 & 19.14 & 9.65 \\
\hline Wastage & 330.62 & 295.57 & 215.36 & 205.23 \\
\hline Others & 5.91 & 5.91 & 4.46 & 2.58 \\
\hline Total & 1128.77 & 990.35 & 759.81 & 545.46 \\
\hline
\end{tabular}

Source: Field survey 2013-14, 1\$=80.00 Taka

Channel-wise marketing cost is shown in Table 4. Channel -1 incurred the highest marketing cost (Tk $1128.77 / 100 \mathrm{~kg}$ ) followed by Channel-2 (Tk 990.35/100 $\mathrm{kg}$ ) and Channel-3 (Tk 759.81). Lowest marketing cost was found in Channel-4 and it was Tk 545.46. Highest numbers of intermediaries were involved in Channel-1 which was the main reasons for higher marketing cost.

\section{Marketing margin and profitability}

In respect of market margin and profitability of intermediaries involved at different levels, there is a variation in market scenario for garlic marketing. Marketing margin was relatively higher in retailer (Tk $1474.72 / 100 \mathrm{~kg}$ ) followed by trader (Tk 676.60/100 kg), local trader (Tk 559.17/100 kg) and wholesaler (Tk $546.19 / 100 \mathrm{~kg}$ ), respectively.

Table 5: Marketing margin and profit of different intermediaries for garlic (Tk/100 kg)

\begin{tabular}{l|c|c|c|c}
\hline Particulars & \multicolumn{4}{|c}{ Intermediaries } \\
\cline { 2 - 5 } & $\begin{array}{c}\text { Local } \\
\text { trader }\end{array}$ & Trader & $\begin{array}{c}\text { Whole } \\
\text { saler }\end{array}$ & Retailer \\
\hline Purchase price (PP) & 5591.67 & 6150.83 & 6827.43 & 7373.62 \\
$\begin{array}{l}\text { Marketing cost (MC) } \\
\text { Sales price (SP) }\end{array}$ & 138.42 & 388.26 & 230.54 & 228.10 \\
$\begin{array}{l}\text { Marketing margin } \\
\text { (MM=SP-PP) }\end{array}$ & 5150.83 & 6827.43 & 7373.62 & 8848.34 \\
$\begin{array}{l}\text { Marketing profit } \\
\text { (MP=MM-MC) }\end{array}$ & 420.75 & 288.33 & 315.65 & 1246.62 \\
\hline
\end{tabular}

Source: Field survey 2013-14, 1\$=80.00 Taka

On the contrary, marketing profit was the highest for retailer (Tk 1246.62/100 kg) followed by local trader (Tk
$420.75 / 100 \mathrm{~kg}$ ), wholesaler (Tk 315.65/100 kg) and trader (Tk 288.33/100 kg), respectively (Tables 5). The marketing profit of trader was the lowest due to pay the highest marketing cost.

\section{Marketing Efficiency}

Marketing efficiency is directly related to the cost involved in moving goods from the producer to the consumer and the quantity of services offered. If the cost incurred when compared with the service involved, is low, it will be efficient marketing. The improvement of marketing efficiency means the reduction of marketing cost without reducing the quantum of services to the consumer. The term marketing efficiency is seen in different perspectives by the marketing personnel and economist. Kohls et al. (2005) defined marketing efficiency as the maximization of input output ratio.

\section{Farmer's share under different marketing channel of garlic}

Farmer's share in consumer prices of garlic in different marketing channels was the highest in Channel-2 followed by Channel-4 and Channel-3 and was lowest in Channel-1 (Table 6).

Table 6: Farmer's share under different major marketing channel of garlic (\%)

\begin{tabular}{l|c|c|c|c}
\hline Particulars & $\begin{array}{c}\text { Channel } \\
-1\end{array}$ & $\begin{array}{c}\text { Channel } \\
-2\end{array}$ & $\begin{array}{c}\text { Channel } \\
-3\end{array}$ & $\begin{array}{c}\text { Channel } \\
-4\end{array}$ \\
\hline $\begin{array}{l}\text { Farmers' price } \\
(\mathrm{Tk} / 100 \mathrm{~kg})\end{array}$ & 5562.62 & 5658.71 & 5562.73 & 5582.71 \\
\hline $\begin{array}{l}\text { Consumer } / \text { retail } \\
\text { price }(\mathrm{Tk} / 100 \mathrm{~kg})\end{array}$ & 8890.11 & 8864.02 & 8831.05 & 8810.15 \\
$\begin{array}{l}\text { Percentage of } \\
\text { farmers' share (\%) }\end{array}$ & 62.57 & 63.84 & 62.99 & 63.37 \\
\hline Rank $\left(\mathrm{I}_{1}\right)$ & $\mathrm{IV}$ & $\mathrm{I}$ & $\mathrm{III}$ & $\mathrm{II}$ \\
\hline
\end{tabular}

Source: Field survey 2013-14, 1\$=80.00 Taka

It indicated that if farmer would sell their garlic through Farmer $\rightarrow$ Trader $\rightarrow$ Commission agent $\rightarrow$ Wholesaler $\rightarrow$ Retailer $\rightarrow$ Consumer, they would be most benefited. Unnecessary marketing tiers develops when there is market imperfection or producer-seller are unorganized and while there is lack of market information or the cost of gathering information is high.

Marketing cost, margin and profit of different channels of garlic

The Channel-1 of garlic marketing has incurred highest marketing cost whereas the lowest in case of Channel-4 (Table 7). It reveals if farmer sell their garlic through Farmer $\rightarrow$ Local trader $\rightarrow$ Trader $\rightarrow$ Commission agent $\rightarrow$ Wholesaler $\rightarrow$ Retailer $\rightarrow$ Consumer, the marketing cost becomes high (Channel-1). On the other hand, if farmer sell their garlic through Channel-4 (Farmer $\rightarrow$ Wholesaler $\rightarrow$ Retailer $\rightarrow$ Consumer) then the marketing cost is the lowest. The data reveals that the highest margin in Channel-1 and the lowest in Channel-2. On the other hand, marketing profit was the highest in Channel-4 and lowest in Channel-1 (Table 7). 
Table 7: Marketing cost, margins and profit of different marketing channel for garlic (Tk/100 kg)

\begin{tabular}{|c|c|c|c|c|}
\hline Particulars & Channel 1 & Channel 2 & Channel 3 & Channel 4 \\
\hline Farmers price & 5562.62 & 5658.71 & 5562.73 & 5582.71 \\
\hline Consumer price/retail price & 8890.11 & 8864.02 & 8831.05 & 8810.15 \\
\hline Marketing margin (MM) & 3327.49 & 3205.31 & 3268.32 & 3227.44 \\
\hline $\operatorname{Rank}\left(\mathrm{I}_{2}\right)$ & IV & $\mathrm{I}$ & III & II \\
\hline Marketing cost (MC) & 1128.77 & 990.35 & 759.81 & 545.46 \\
\hline Rank $\left(\mathrm{I}_{3}\right)$ & IV & III & II & $\mathrm{I}$ \\
\hline Marketing profit (MP=MM-MC) & 2198.72 & 2214.96 & 2508.51 & 2681.98 \\
\hline Rank $\left(\mathrm{I}_{4}\right)$ & $\mathrm{I}$ & II & III & IV \\
\hline
\end{tabular}

Source: Field survey 2013-14, 1\$=80.00 Taka

\section{Efficiency of different marketing channels of garlic}

The efficiency of different marketing channels was drawn as the basis of ranks of different performance indicators in different channels using Composite Index Method. The performance indicators revealed that the Channel-2 is more efficient than that of other channels (Table 8).

Table 8: Marketing efficiency garlic under Composite Index Method

\begin{tabular}{|c|c|c|c|c|c|c|c|}
\hline \multirow{2}{*}{$\begin{array}{l}\text { Marketing } \\
\text { Channel/ } \\
\text { Rank }\end{array}$} & \multicolumn{7}{|c|}{ Score as performance indicators } \\
\hline & $\begin{array}{c}\text { Farmer's share } \\
(\%)\left(\mathrm{I}_{1}\right)\end{array}$ & $\begin{array}{l}\text { Marketing } \\
\text { margin } \\
(\mathrm{Tk} / 100 \mathrm{~kg}) \\
\left(\mathrm{I}_{2}\right)\end{array}$ & $\begin{array}{l}\text { Marketing } \\
\text { cost (Tk/ } 100 \\
\text { kg) } \\
\left(\mathrm{I}_{3}\right)\end{array}$ & $\begin{array}{c}\text { Marketing } \\
\text { profit (Tk/ } 100 \\
\mathrm{~kg}) \\
\left(\mathrm{I}_{4}\right)\end{array}$ & $\begin{array}{l}\text { Total } \\
\text { score }\end{array}$ & $\begin{array}{l}\text { Mean } \\
\text { score }\end{array}$ & Rank \\
\hline Channel-1 & 62.57 & 3327.49 & 1128.77 & 2198.72 & & & \\
\hline Rank & 4 & 4 & 4 & 1 & 13 & 3.25 & IV \\
\hline Channel -2 & 63.84 & 3205.31 & 990.35 & 2214.96 & 7 & 175 & \\
\hline Rank & 1 & 1 & 3 & 2 & 7 & 1.75 & 1 \\
\hline Channel -3 & 62.99 & 3268.32 & 759.81 & 2508.51 & 11 & 275 & II \\
\hline Rank & 3 & 3 & 2 & 3 & 11 & 2.75 & 111 \\
\hline Channel -4 & 63.37 & 3227.44 & 545.46 & 2681.98 & 0 & 225 & II \\
\hline Rank & 2 & 2 & 1 & 4 & 9 & 2.20 & 11 \\
\hline
\end{tabular}

Source: Field survey 2013-14

\section{Value Chain Analysis of Garlic}

Economic value chain analysis describes the range of activities required to bring a product to the final consumer (Jacinto, 2004). This includes activities such as design, production, marketing, distribution and support services to final consumer. A traditional food industry value chain consists of the producer, processor, wholesaler, exporter, importer, retailer and consumer. This study analyzes how market intermediaries operate along garlic value chains, and demonstrates how the revenue from garlic trade is distributed over the entire garlic value chain.

\section{Value chain mapping}

Value chain analysis plots the flow of goods and services up and down the chain, and between different chains. Mapping of value chains obtains a clear understanding of the sequence of activities and the key actors and relationships involved in the value chain.

The row at the top side showed different functions of the actors' respectively garlic production, collection, wholesaling, retailing and consuming. The diagram at the right side present all the actors involved-farmer, local trader, trader, commission agent, wholesaler, retailer and consumer, and the link and products flow between them (Figure 2).
Figure 2: Value chains map of garlic in domestic market

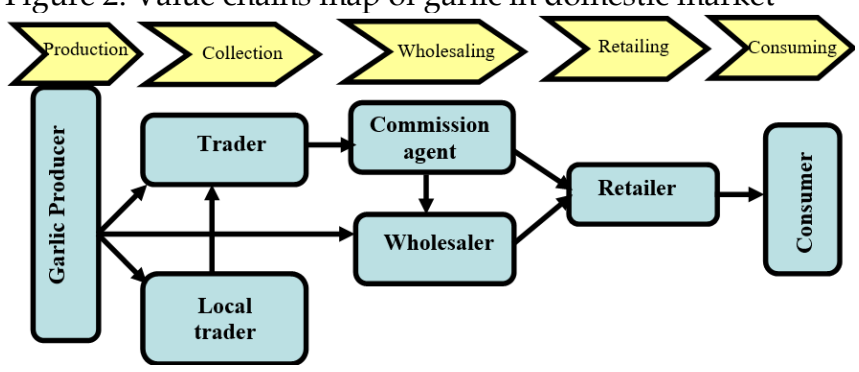

Distribution of value addition

Each of the garlic value chain actors adds value to the product as the product passes from one actor to another. In a way, the actors change the form of the product through processing or improve the grade through sorting, cleaning or washing or create space and time utility. The distribution of value addition among the garlic value chain actors in Bangladesh is depicted in Table 9.

Value addition is the difference in sales price and purchase price at each stage of the value chain. Garlic producers reported lower price of Tk 5591.67 per $100 \mathrm{~kg}$ by adding a value of Tk 877.15 which is $21.22 \%$ of the total value added in Bangladesh. Local trader added value Tk 559.16 and that of trader Tk 676.60 per 100 $\mathrm{kg}$ of garlic which was 13.53 and $16.37 \%$ of the total value added, respectively. Wholesalers add the least $(13.21 \%)$ and the retailers add Tk 1474.72 per $100 \mathrm{~kg}$ which is about $36 \%$ of the total value added (Table 9). 
Table 9: Distribution of value addition among major chains of garlic (Tk/100 kg)

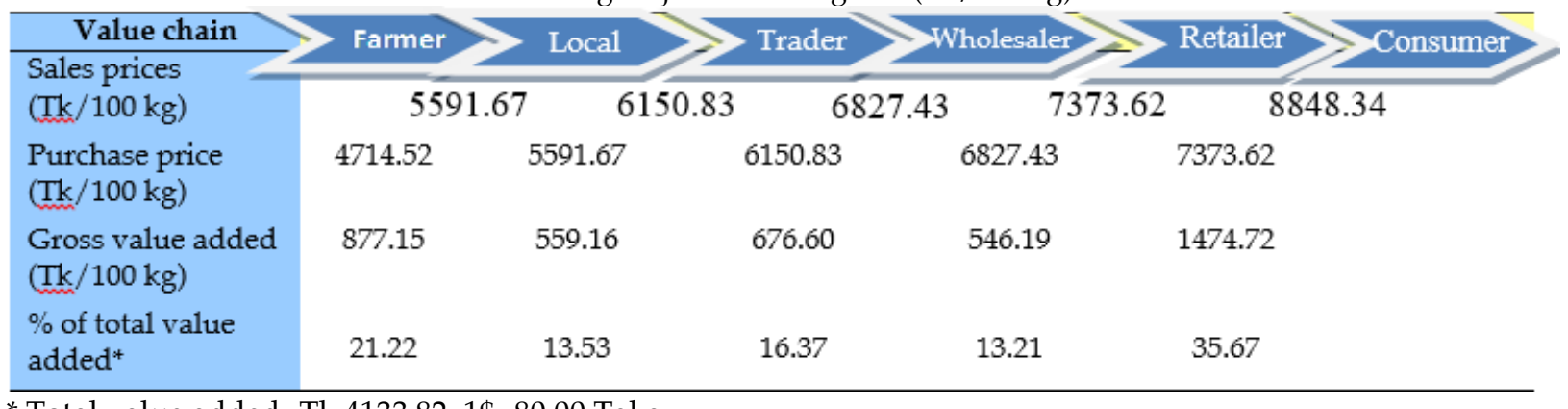

* Total value added $=$ Tk 4133.82, $1 \$=80.00$ Taka

The price change from producer's price and consumer price is $58 \%$. The highest profit is earned by the retailers due selling high price of per unit of garlic to the consumer. The scale of operation of the retailers is small. On the other hand, the wholesalers make a small profit margin per unit of garlic handled but their operational scale was high making them the dominant value chain actors.

\section{Constraints in garlic value chain}

One of the merits of value chain approaches is that it helps to clearly identify bottlenecks to the development of the chain right from input supply up until the consumption level in various ways. Table 10 summarized the constraints identified in this study which is common for all areas.

Table 10: Core constraints in garlic value chain

\begin{tabular}{|c|c|c|c|c|c|}
\hline Input supply & Production & Marketing/Trading & Processing & Retailing & Consumption \\
\hline $\begin{array}{l}\text { - Shortage of } \\
\text { improved and } \\
\text { quality seed } \\
\text { - Damaged } \\
\text { and spoiled } \\
\text { seed due to } \\
\text { poor transporting } \\
\text { and handling }\end{array}$ & $\begin{array}{l}\text { - Low yield } \\
\text { Low irrigation } \\
\text { facility; } \\
\text { - Poor disease } \\
\text { control } \\
\text { - Less targeted } \\
\text { to seed production }\end{array}$ & $\begin{array}{l}\text { - Perishability } \\
\text { - Low skill in } \\
\text { post-harvest } \\
\text { management } \\
\text { - Lack of } \\
\text { storage facility }\end{array}$ & $\begin{array}{l}\text { - Lack of } \\
\text { processing } \\
\text { facilities; } \\
\text { - Low skill } \\
\text { and technology } \\
\text { for processing }\end{array}$ & $\begin{array}{l}\text { - Lack of facilities; } \\
\text { - Lack of capital }\end{array}$ & $\begin{array}{l}\text { - Limited } \\
\text { dishes / } \\
\text { recipes }\end{array}$ \\
\hline
\end{tabular}

Ten marketing problems indicated by farmers included in the study areas. Among them low price of garlic, price fluctuation, high transport cost, and lack of loan facilities were the major problem of farmer for marketing garlic in Bangladesh. Local trader reported price fluctuation, high transport cost, and lack of loan facilities were their main problem. Table 11 showed that value chain actor faced eleven problem of which price fluctuation, high transport cost, lack of truck to transport and lack of loan facilities were their main problem. $100 \%$ trader cited that price fluctuation and high transport cost are the major problem for garlic marketing. In the study areas, wholesalers indicated the main problem as price fluctuation, poor road and shortage of store house. On the other hand, retailers reported price fluctuation, poor road and perishability of garlic was their main problem (Table 11).

Table 11: Marketing problems of value chain actor for garlic marketing ( $\%$ of respondents)

\begin{tabular}{|c|c|c|c|c|c|}
\hline Marketing problem & $\begin{array}{l}\text { Farmer (\%) } \\
(\mathrm{N}=120)\end{array}$ & $\begin{array}{l}\text { Local trader }(\%) \\
(\mathrm{N}=36)\end{array}$ & $\begin{array}{l}\text { Trader }(\%) \\
(\mathrm{N}=45)\end{array}$ & $\begin{array}{l}\text { Wholesaler }(\%) \\
(\mathrm{N}=30)\end{array}$ & $\begin{array}{l}\text { Retailer } \\
(\mathrm{N}=30)\end{array}$ \\
\hline Low price of garlic & 83 & - & - & - & - \\
\hline High seed garlic price & 67 & - & - & - & - \\
\hline Price fluctuation & 92 & 83 & 100 & 93 & 60 \\
\hline Bribery/donation & 33 & 67 & 36 & 33 & 40 \\
\hline Lack of local market & 29 & 28 & - & - & - \\
\hline High transport cost & 83 & 89 & 100 & 53 & 33 \\
\hline Poor road & 33 & 50 & 40 & 60 & 60 \\
\hline $\begin{array}{l}\text { Shortage of truck to } \\
\text { transport }\end{array}$ & - & - & 89 & 47 & 43 \\
\hline Perishability & 58 & 58 & 56 & 40 & 70 \\
\hline Shortage of store house & 63 & 42 & 67 & 73 & - \\
\hline Lack of loan facility & 85 & 78 & 93 & 43 & 50 \\
\hline
\end{tabular}

Source: Computed from producer survey data

Note: Multiple responses is possible 


\section{CONCLUSION}

The results of the study depicted that domestic produced garlic runs through the four major marketing channels from farmer to consumer. Channel-3 was the most important supply chain of which through $40 \%$ domestic produced garlic reaches to consumers. Marketing costs per $100 \mathrm{~kg}$ of garlic were estimated from Tk 86.82 to 388.28 and marketing margin Tk 546.19 to 1474.72 , respectively for different intermediaries. Marketing margin and profit were the highest in retailer than those of other intermediaries. The study showed, out of four marketing channel, Channel-2 was more efficient than those of other channels. Six actors like; farmer, local trader, trader, commission agent, wholesaler, retailer and consumer are identified who are involved in the garlic value chain. The study revealed that retailer added highest amount of value of garlic followed by producers, trader, local trader and wholesalers, respectively. Eleven marketing problem were identified, among them price fluctuation, high transport cost and lack of loan facilities were the major and common problem for all kinds of intermediaries involved in garlic marketing in Bangladesh.

\section{Recommendations for Value Chain DEVELOPMENT}

A value chain consists of the producers, local traders, trader, commission agent, wholesalers, retailers and consumers that bring garlic from its conception to its end use. Constraints often include a lack of technical, business or financial support services, lack or a difficult regulatory framework, poor public infrastructure (roads, electricity, etc.), a lack of information about or weak connections to end markets, and/or inadequate coordination between firms. A summary of the recommendations is given below-

\section{SUMMARY OF INTERVENTIONS}

\section{Input supply}

- Establish and strengthen cooperatives or groups that engage in garlic seed bulb production to achieve the economies of scale needed to meet producers' high demand for improved garlic seed;

- Introducing improved seed production and marketing system can significantly contribute to the solution. The garlic seed bulb producers can then be linked with garlic producers to create access to market for their business.

- Farmers continue to use local garlic variety from many times ago. Improved variety of garlic seed bulb replacement system should be put in place by involving the relevant stakeholders like Department of Agricultural Extension, NGO's, Research Institutions and Seed Producers. The system should enable farmers to replace the improved varieties at regular interval.

\section{Storage facilities}

Garlic is semi perishable agricultural product. In all the study areas lack of storage house and facilities for table and seed purpose garlic was raised by farmers and other actors as a priority problem. Low cost technology for garlic storage should be developed and disseminates to the farmer. Except this, loan facilities should provide to farmer so, the farmer can made storage house for garlic.

\section{Production}

Producing diverse types of garlic varieties can create attractive market. From consumer surveys, it was learnt that preference for garlic varies from location to location and by consumer type. Institutions and restaurants prefer large sized clove garlic that can be easily peeled. Household consumers prefer medium sized pungent varieties. BARI Rashun-2 which is released from Spices Research Centre of BARI is a medium sized pungent variety. This variety is very preferable to consumer but seed is in short supply.

BADC should produce huge amount of seed bulb of this variety; so that the farmer could get it easily. Garlic specific technical recommendations should be adequately disseminated to increase garlic production and productivity. The extension service should take up garlic as essential commodity and enhance its productivity.

\section{Transportation}

In the garlic market survey, it was observed that garlic is transported over long distance by packing gunny or netted bag. During loading and unloading, there is mishandling of the products which lead to quick spoilage and high loss. It is important to establish garlic transportation standards and enforce it;

\section{Marketing}

- Market infrastructure should be developed in terms of quick transportation, proper storage and other physical facilities to reduce spoilage and damage.

- Organize and capacitate producers to enhance their negotiation power and skill.

- Create value chain forum at village level where the different value chain actors come together and discuss the problems of garlic value chain and solve them.

\section{Processing}

Garlic processing facilities should be developed. Introduction of improved varieties of garlic will increase the supply. Along this, it is important to introducing garlic processing facilities that can induce consumption and also increase shelf life of the product. Involving the private sector in the enhancement of the processing of garlic can result in sustainability of the intervention.

\section{Consumption}

- The demand for the product in the total consumption bundle of rural and urban consumers is small which means that the product fetches low price. The low consumption attributes to lack of knowledge to prepare different recipe, dishes, and products from garlic by 
most consumers in Bangladesh. Therefore, promotion of garlic utilization by demonstrating different ways of utilizing garlic for food can induce higher demand thereby motivating the producers to produce more.

- At an industry level, nearly no one is processing garlic. Garlic reduces blood pressure and cholesterol. Garlic tablet produced from garlic. In the production of garlic tablet, it will be necessary to bring on the potential industries.

\section{REFERENCES}

Abbott, J.C. (1986). Marketing Improvement in the Developing World: What Happens and What We Have Learned. FAO Economic and Social Development Series No. 37. Rome: Food and Agriculture Organization.

Arene, C.J. (1999). Introduction to Agricultural Marketing Analyses for Developing Economics. Fulladu Publishing Company, Nsukka, 15-23.

BBS. 1998 and 2015. Year book of Agricultural Statistics of Bangladesh. Bureau of Statistics, Ministry of Panning, Dhaka, Bangladesh.
Ikechi, K., et al. (2006). The performance of vegetable production and marketing in Aba area, Abia State. Proceedings of the 40th conference of Agricultural Society of Nigeria, held in Umudike. Abia State, 133-134.

Jacinto, E.R. 2004. A Research Framework on Value Chain Analysis in Small Scale Fisheries. Paper Presented to the $10^{\text {th }}$ Biennial Conference of the International Association for Study of Common Property, Oaxaca, México, 9-13 August 2004, p.27.

Kohls, R.L and Uhl, J.N 2005. Marketing of agricultural products. $9^{\text {th }}$ edition. Macmillan publishing co., Inc., New York.

Reardon, T. and C. Timmer (2007). "Transformation of markets for agricultural output in developing countries since 1950: How has thinking changed?" in Handbook of Agricultural Economics. Vol. 3: 2807-2855

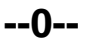




\section{ApPendices}

Appendix Table 1: All marketing channel for Garlic in selected areas

\begin{tabular}{|c|c|c|c|}
\hline Channel & Marketing channel & $\%$ of garlic run & Rank (I) \\
\hline 1. & Farmer $\rightarrow$ Local trader $\rightarrow$ Trader $\rightarrow$ Commission agent $\rightarrow$ Wholesaler $\rightarrow$ Retailer $\rightarrow$ Consumer & 14 & III \\
\hline 2. & Farmer $\rightarrow$ Trader $\rightarrow$ Commission agent $\rightarrow$ Wholesaler $\rightarrow$ Retailer $\rightarrow$ Consumer & 20 & II \\
\hline 3. & Farmer $\rightarrow$ Trader $\rightarrow$ Commission agent $\rightarrow$ Retailer $\rightarrow$ Consumer & 40 & I \\
\hline 4. & Farmer $\rightarrow$ Wholesaler $\rightarrow$ Retailer $\rightarrow$ Consumer & 3 & VII \\
\hline 5. & Farmer $\rightarrow$ Retailer $\rightarrow$ Consumer & 2 & VI \\
\hline 6. & Farmer $\rightarrow$ Consumer & 1 & VIII \\
\hline 7. & Importer $\rightarrow$ Commission agent $\rightarrow$ Wholesaler $\rightarrow$ Retailer $\rightarrow$ Consumer & 8 & V \\
\hline 8. & Importer $\rightarrow$ Commission agent $\rightarrow$ Retailer $\rightarrow$ Consumer & 12 & IV \\
\hline
\end{tabular}

Appendix Table 2: Per hectare cost of garlic (Tk) production in Bangladesh

\begin{tabular}{|c|c|c|c|c|c|c|c|c|}
\hline \multirow[t]{2}{*}{ Cost items } & \multicolumn{2}{|c|}{ Small farm } & \multicolumn{2}{|c|}{ Medium farm } & \multicolumn{2}{|c|}{ Large farm } & \multicolumn{2}{|c|}{ All farm } \\
\hline & Tk/ha & $\%$ & Tk/ha & $\%$ & Tk/ha & $\%$ & Tk/ha & $\%$ \\
\hline A. Variable cost & 187162 & 84.89 & 176952 & 84.14 & 172585 & 83.75 & 179006 & 84.28 \\
\hline \multicolumn{9}{|c|}{ Operational input (Using human labour) } \\
\hline Land preparation & 2378 & 1.08 & 1902 & 0.90 & 1902 & 0.92 & 2061 & 0.97 \\
\hline Sowing/Plantation & 10303 & 4.67 & 10144 & 4.82 & 9827 & 4.92 & 10144 & 4.78 \\
\hline $\begin{array}{l}\text { Manure and fertilizer } \\
\text { application }\end{array}$ & 1585 & 0.72 & 1427 & 0.68 & 1585 & 0.69 & 1585 & 0.75 \\
\hline Irrigation & 1110 & 0.50 & 1268 & 0.60 & 951 & 0.62 & 1110 & 0.52 \\
\hline Inter-culture operation & 18703 & 8.48 & 17435 & 8.29 & 16167 & 8.46 & 17435 & 8.21 \\
\hline Plant protection measures & 1268 & 0.58 & 1110 & 0.53 & 1110 & 0.54 & 1110 & 0.52 \\
\hline $\begin{array}{l}\text { Harvesting, transporting } \\
\text { and processing }\end{array}$ & 17277 & 7.84 & 16167 & 7.69 & 15533 & 7.85 & 16326 & 7.69 \\
\hline Total operating cost & 52622 & 23.87 & 49452 & 23.51 & 47075 & 24.00 & 49769 & 23.43 \\
\hline \multicolumn{9}{|l|}{ Material cost } \\
\hline Seed/seedlings & 96900 & 43.95 & 94146 & 44.77 & 92310 & 45.69 & 94452 & 44.47 \\
\hline Power tiller/Ploughing & 6478 & 2.94 & 5787 & 2.75 & 5450 & 2.81 & 5905 & 2.78 \\
\hline Irrigation & 6433 & 2.92 & 5560 & 2.64 & 5200 & 2.70 & 5731 & 2.70 \\
\hline Manure & 3861 & 1.75 & 3514 & 1.67 & 3980 & 1.71 & 3785 & 1.78 \\
\hline \multicolumn{9}{|l|}{ Fertilizers } \\
\hline Urea & 2904 & 1.32 & 2460 & 1.17 & 2376 & 1.19 & 2580 & 1.21 \\
\hline TSP & 3674 & 1.67 & 2750 & 1.31 & 2332 & 1.33 & 2926 & 1.38 \\
\hline MP & 4850 & 2.20 & 3850 & 1.83 & 3525 & 1.87 & 4075 & 1.92 \\
\hline DAP & 2250 & 1.02 & 2100 & 1.00 & 2760 & 1.02 & 2370 & 1.12 \\
\hline Zink & 750 & 0.34 & 1200 & 0.57 & 1500 & 0.58 & 1200 & 0.56 \\
\hline Gypsum & 360 & 0.16 & 750 & 0.36 & 520 & 0.36 & 540 & 0.25 \\
\hline $\begin{array}{l}\text { Plant protection } \\
\text { (Insecticides/fungicides) }\end{array}$ & 6080 & 2.76 & 5383 & 2.56 & 5557 & 2.61 & 5673 & 2.67 \\
\hline Total material cost & 134540 & 61.02 & 127500 & 60.63 & 125510 & 61.87 & 129237 & 60.85 \\
\hline \multicolumn{9}{|l|}{ B. Overhead cost } \\
\hline Lease value of land & 30200 & 13.70 & 30400 & 14.46 & 30600 & 14.85 & 30400 & 14.31 \\
\hline $\begin{array}{l}\text { Interest on working capital } \\
@ 10 \text { percent (per crop } \\
\text { cycle) }\end{array}$ & 3119 & 1.41 & 2949 & 1.40 & 2876 & 1.40 & 2983 & 1.40 \\
\hline Total overhead cost & 33319 & 15.11 & 33349 & 15.86 & 33476 & 16.25 & 33383 & 15.72 \\
\hline Total cost $(\mathrm{A}+\mathrm{B})$ & 220481 & 100.0 & 210301 & 100.0 & 206061 & 100.0 & 212389 & 100.0 \\
\hline
\end{tabular}

Source: Field survey, 2013-14.

Appendix Table 3: Per quintal cost of garlic production

\begin{tabular}{llllll}
\hline \multicolumn{1}{c|}{ Items } & Small farmers & Medium farmers & Large farmers & All farmers \\
\hline Bulb garlic (kg/ha) & 4610 & 4515 & 4390 & 4505 \\
Total cost (Tk/ha) & 220481 & 210301 & 206061 & 212389 \\
Cost per quintal (Tk) & 4782.67 & 4657.83 & 4693.87 & 4714.52 \\
\hline
\end{tabular}

Source: Field survey, 2013-14. 


\section{SOCIAL SCIENCE RESEARCH NETWORK}

2171 Monroe Avenue, Suite 203, Rochester, NY 14618, USA

http://www.ssrn.com/en/

AJTP Link: http://www.ssrn.com/link/American-Journal-Trade-Policy.html 